\title{
The Austro-Hungarian hangars in Mostar - Part I
}

\author{
Gottfried Holzschuh \\ Art, construction and aviation historian, archaeologist, Vienna, Ph.D. \\ Curator (ret.) of the Esterházy Collections, Eisenstadt, g.holzschuh@kabelplus.at
}

\begin{abstract}
The first part of the survey covers the history of the Austro-Hungarian "Air Base", "Aviation Park no. 4" and "Reserve Squadron 11", which were stationed in Mostar between 1913 and 1918. The airfield of Mostar-Rodoč, evaluated as early as in 1912, was one of the oldest in the Austro-Hungarian Monarchy. The Imperial and Royal Army Air Service used it for basic pilot training in World War I. The second part is an expertise for the salvage, conservation and restoration of the four still existing Austro-Hungarian hangars at the former Mostar-Rodoč airfield in view of protection of historical monuments. Erected in 1917/18, these hangars are the oldest witnesses of aviation in Bosnia and Hercegovina. Because of their genuine and very efficient construction, they should be preserved as unique examples of technical and engineering architecture. One hangar of exactly the same type, restored in 2013 in Krakow, is now part of Poland's cultural heritage. Structural calculations have shown that these Austro-Hungarian hangars comply with modern EU building regulations. All used documents and plans from the Austrian State Archives/War Archives (ÖStA/KA) in Vienna are still unpublished. The paper is therefore the first scientific analysis of Austro-Hungarian aviation and its architecture in Bosnia and Hercegovina.
\end{abstract}

Key words: World War I, Austro-Hungarian aviation, Imperial and Royal Army Air Service in Bosnia and Hercegovina, Mostar-Rodoč airfield, hangar, preservation, cultural heritage

\section{Austrougarski zrakoplovni hangari u Mostaru - I. dio}

Sažetak: Prvi dio studije obuhvaća povijest k.u.k. „Zrakoplovne baze“, „Avijatičarskog parka br. 4“ i "Rezervne eskadrile 11“, koji su između 1913. i 1918. godine bili stacionirani u Mostaru. Uzletište Mostar-Rodoč, čija je svrha ispitana već 1912., bilo je jedno od najstarijih u Monarhiji. K.u.k. avijatičarske trupe su ga koristile tijekom Prvog svjetskog rata za osnovno obrazovanje svojih pilota. Drugi dio donosi ekspertizu spašavanja, održavanja i obnove četiri još postojeća k.u.k. hangara na nekadašnjem uzletištu Mostar-Rodoč s gledišta održavanja spomenika. Hangari izgrađeni 1917./18. predstavljaju najstarije svjedoke zrakoplovstva u Bosni i Hercegovini. Zbog svoje jedinstvene i vrlo učinkovite vrste konstrukcije trebali su se očuvati kao neponovljivi primjeri tehničko-inženjerske arhitekture. Jedan hangar potpuno iste vrste, obnovljen 2013. u Krakovu spada danas u kulturnu baštinu Poljske. Statički proračuni pokazali su da ovi k.u.k. hangari odgovaraju suvremenim građevinskim propisima EU-e. Sav korišteni izvorni i planski materijal iz Austrijskog državnog/ratnog arhiva (ÖStA/KA) u Beču nije do danas objavljen - time rad predstavlja prvu znanstvenu analizu/raspravu o k.u.k. zrakoplovstvu i njegovoj arhitekturi u Bosni i Hercegovini.

Ključne riječi: Prvi svjetski rat, austrougarska avijacija, K.u.k. avijatičarske trupe u Bosni i Hercegovini, uzletište u Mostaru-Rodoč, hangar, zaštita spomenika, kulturna baština

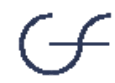




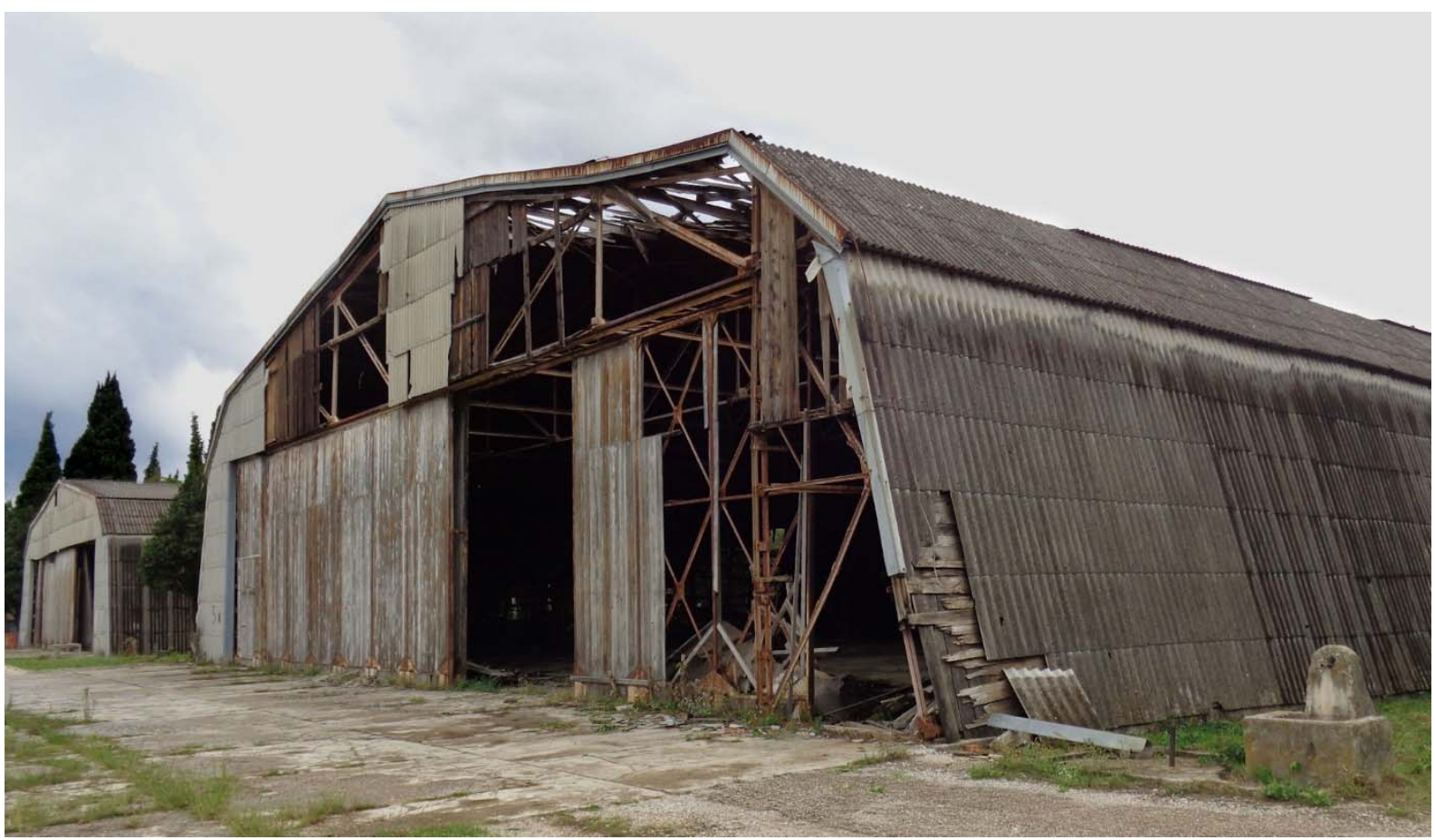

Figure 1. Important witnesses of early aviation in Bosnia and Hercegovina: hangars in Mostar (M. Martinović)

Among the many buildings that were left behind by the Austro-Hungarian military administration in the Monarchy's successor states and that are still in use for a wide variety of purposes, there are still some Army Air Service hangars that have survived. Mostly located in the areas of barracks that are still in use, they have remained hidden from the public. In some cases, the monument preservation has already noticed their rarity and thereby their historical preciousness and restored them for museum purposes. Thus, these buildings in Austria, Italy, Poland and the Czech Republic are the oldest surviving witnesses of the aviation history of their country. The rest have been left to decay or generally demolished long ago.

Some more historic hangars have also been preserved at the former Austro-Hungarian airfield Rodoč near Mostar, located in the Herzegovinian part of the present Federation of Bosnia and Herzegovina. They are located on military property of the Bosnian and Herzegovinian armed forces. Other buildings that are part of this area are presently used by the state University's Faculty of Science and Education. Four of these iron hangars undoubtedly originated at times of the Monarchy. Although they survived the battles around Mostar in 1992/93 and 1993/94 during the war in Bosnia and Herzegovina, they have since been left to decay without proper use (Figures 1,2).

\section{AIR BASE}

The airfield Rodoč near Mostar was one of the oldest aviation facilities in Austria-Hungary. Already in late 1912, the Imperial and Royal Military Administration evaluated conditions for a possible air base in the area of Mostar, the center of Herzegovina. The motives were to build strong garrisons also in remote and less convenient parts of the country and thus demonstrate military presence. The Imperial and Royal Aviation Division gave priority to an area south of Mostar near Gnojnice on the left bank of Neretva. The advantage was that the 
Holzschus, G.

The Austro-Hungarian hangars in Mostar - Part I

useless meadows in question were mostly owned by the state government, and only a small part of them were privately owned. Furthermore, there was a "Vineyard Station", which had to be abandoned in order to be used "if possible to accommodate an air station". Before the state owned land was released to the Military Administration, the choice fell on an area on the right bank of the river south of the Hum hill near Rodoč, the pasture of which looked better suited for an airfield complex (see Overview Map, Figure 3). An area of 1,200,180 square meters, located in the cadastral municipalities of Rodoč and Jasenica, was purchased by the Military Administration for 116,197 kronen. Only a small part consisting of arable land had to be expropriated (Figure 4).

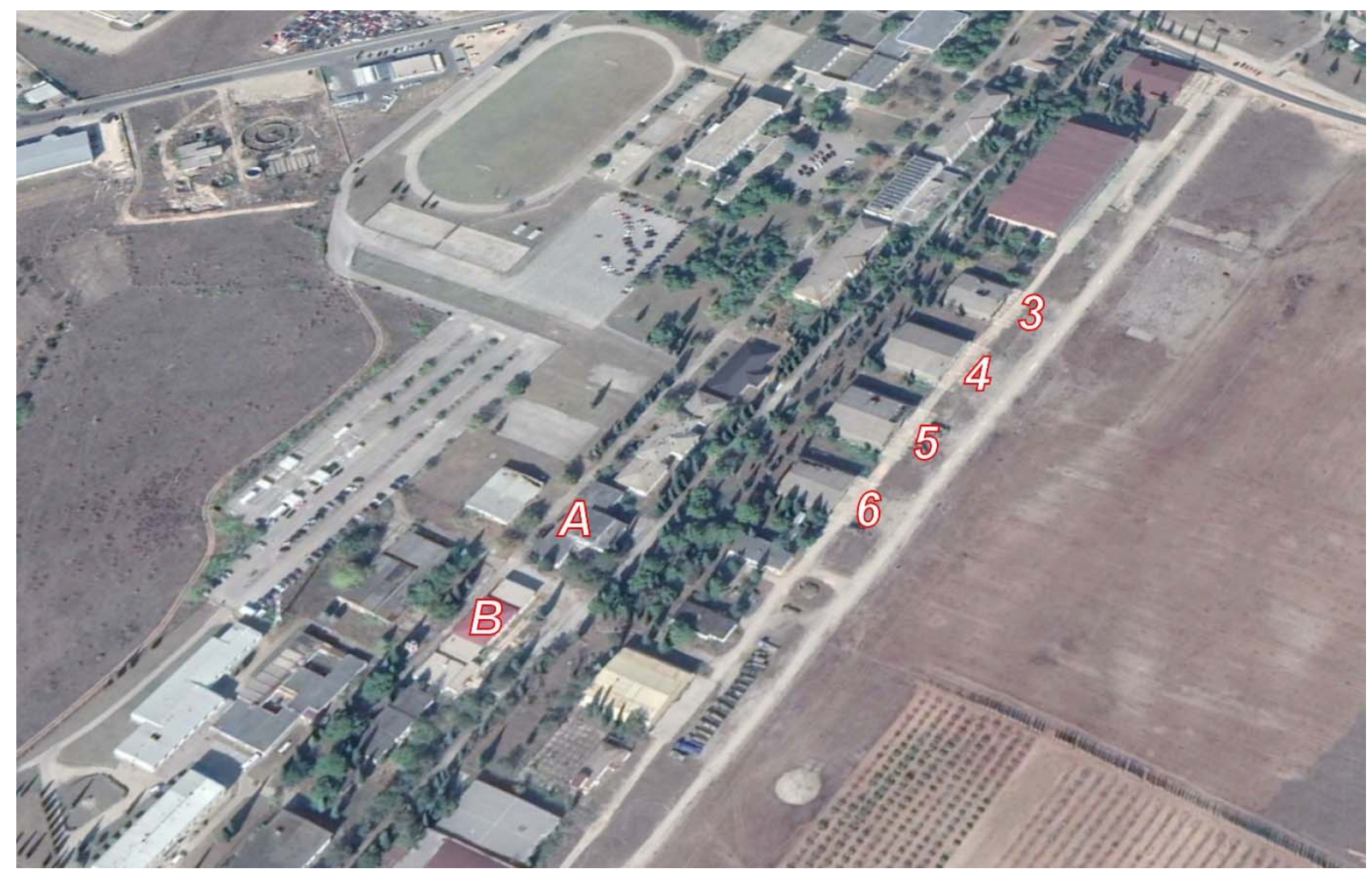

Figure 2. Contemporary aerial view of the former Mostar-Rodoč airfield from the southeast. Preserved Austro-Hungarian buildings are marked as no. 3 to 6 iron hangars, A - residential building, B - workshop (Google Earth)

An aviation park was established at the beginning of May 1913, and Combat Pilot Captain Deodatus Andrich (* 4 May 1875, Trieste, † 17 May 1913, Čapljina, Herzegovina, Figure 5) was appointed its commander. On May 17, Andrich undertook a reconnaissance flight to the Montenegrin border with passenger Josef Flassing, a lieutenant of the Fortress Artillery Regiment no. 4 at 9:11 on a type B Lohner Pfeilflieger plane named "Bob". The route was supposed to run from Mostar via Nevesinje - Avtovac - Bileća - Trebinje and again to Mostar, but they did not return to the airfield at the expected time. As it soon turned out, they had crashed around 12:05 800 m south of the bridge over Neretva in Čapljina. Andrich was seriously injured with a base skull fracture, while Flassing was slightly injured only. Even before the arrival of a detachment from the aviation park. Andrich died of the sustained injuries at 14:45 in the hospital ward of the Imperial and Royal Territorial Army Infantry Regiment no. 23 "Zara". According to Lieutenant Flassing, due to the gusty storm the flight over the hills was so turbulent that they had to disgorge several times. Near Capljina, the obviously weakened Andrich tried to make an emergency landing, but probably lost 
Holzschus, G.

The Austro-Hungarian hangars in Mostar - Part I

consciousness. The plane somersaulted and Flassing was thrown out of the cockpit with a torn seat belt. Andrich's body and the remains of the Lohner Pfeilflieger plane were returned to Mostar by railway. Andrich was buried on 17 May at the Military Cemetery in Mostar.

The third plane crash with a fatal outcome since the establishment of the Air Service incurred a painful and precise investigation by the Austro-Hungarian Aviation Division. Although Andrich was playing cards at the Herzegovina coffee house until 3:20 in the morning on the day of the accident, according to witness accounts, he did not drink alcohol then or the day before. As a flier, he was reportedly not the last victim of bora storm.

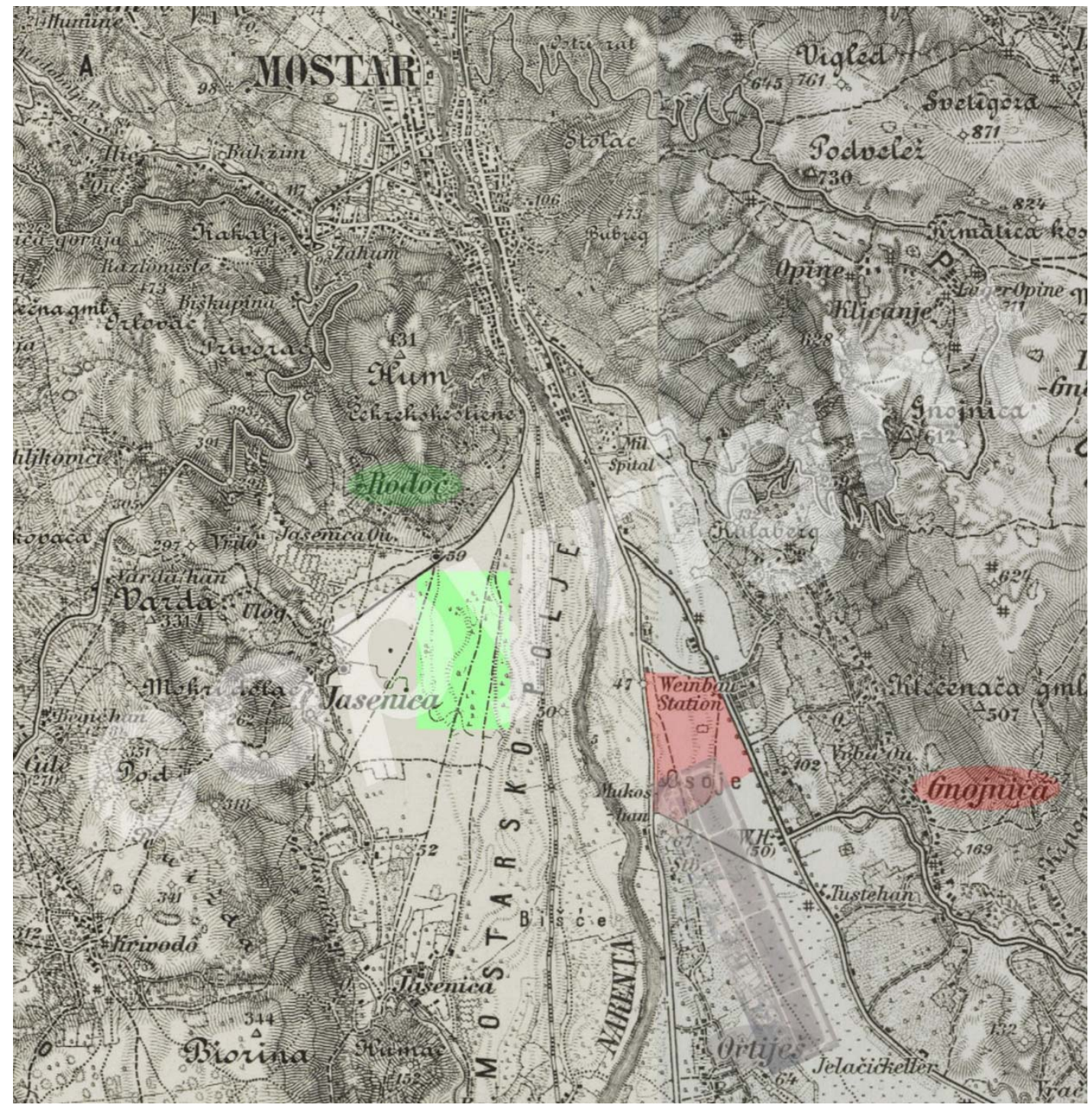

Figure 3. Planned (red) and constructed (green) Austro-Hungarian airfield Mostar. Today's Mostar-Ortiješ Airport is also added as a phantom image (Basic map: special map of the Military Geographical Institute from 1911)

On 1 July 1913, the Ministry of War decided to construct the following buildings on the new airfield, which was to be used as a training field for basic flying, by the end of the year:

a large residential building for approximately 60 men (construction costs 100,000 kr.), an aircraft depot (for 70,000 kronen),

a workshop (50,000 kronen), and 
Holzschus, G.

The Austro-Hungarian hangars in Mostar - Part I

a hangar (6,000 kronen).

The total amount was provided from the financial resources of Department 5/M of the Ministry of War. The buildings - without the hangar - were reportedly not completed until 1914 (see Figures 6 to 10).

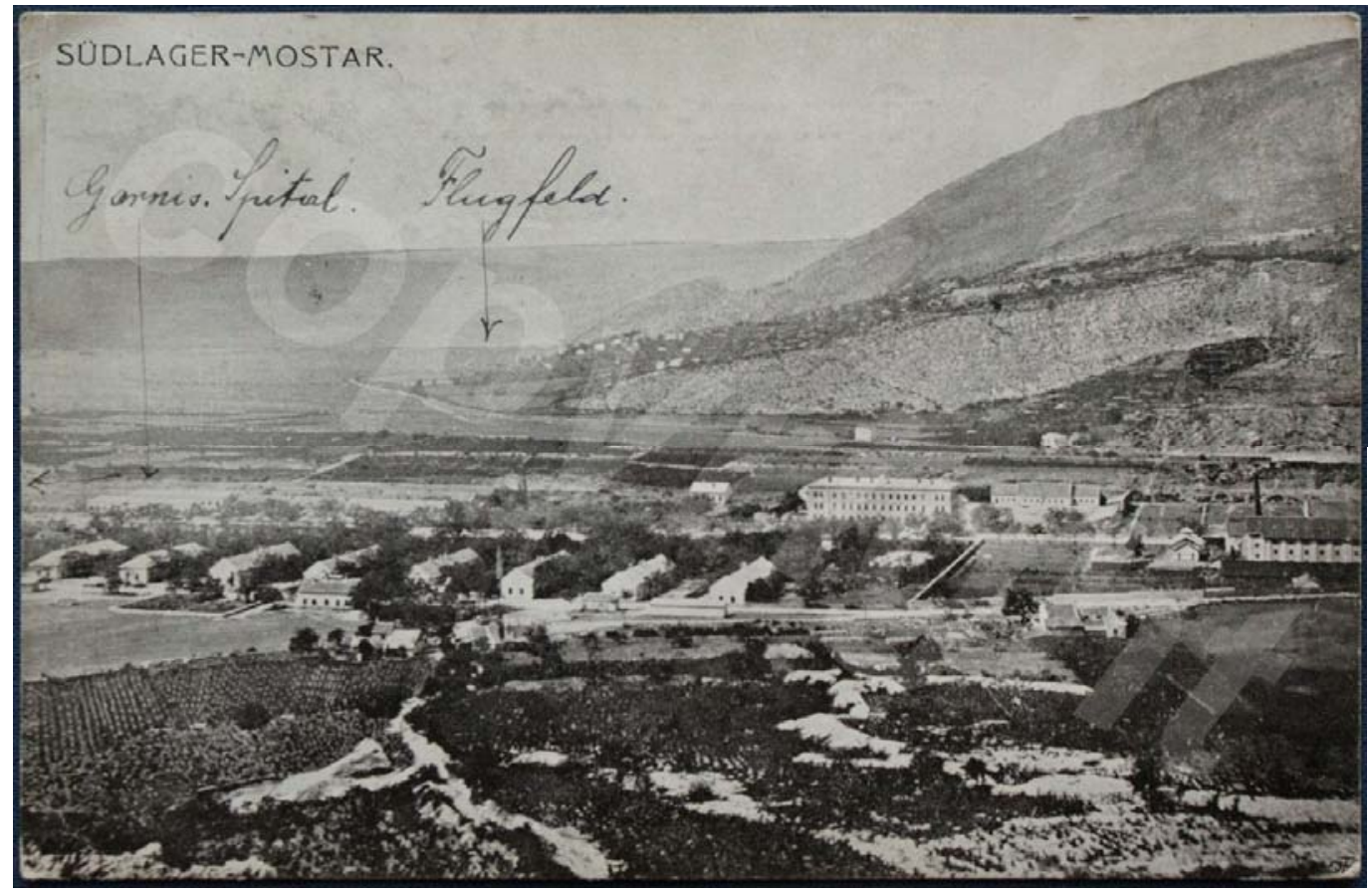

Figure 4. Postcard of Mostar with garrison hospital and airfield in the background (by A. Kustan)

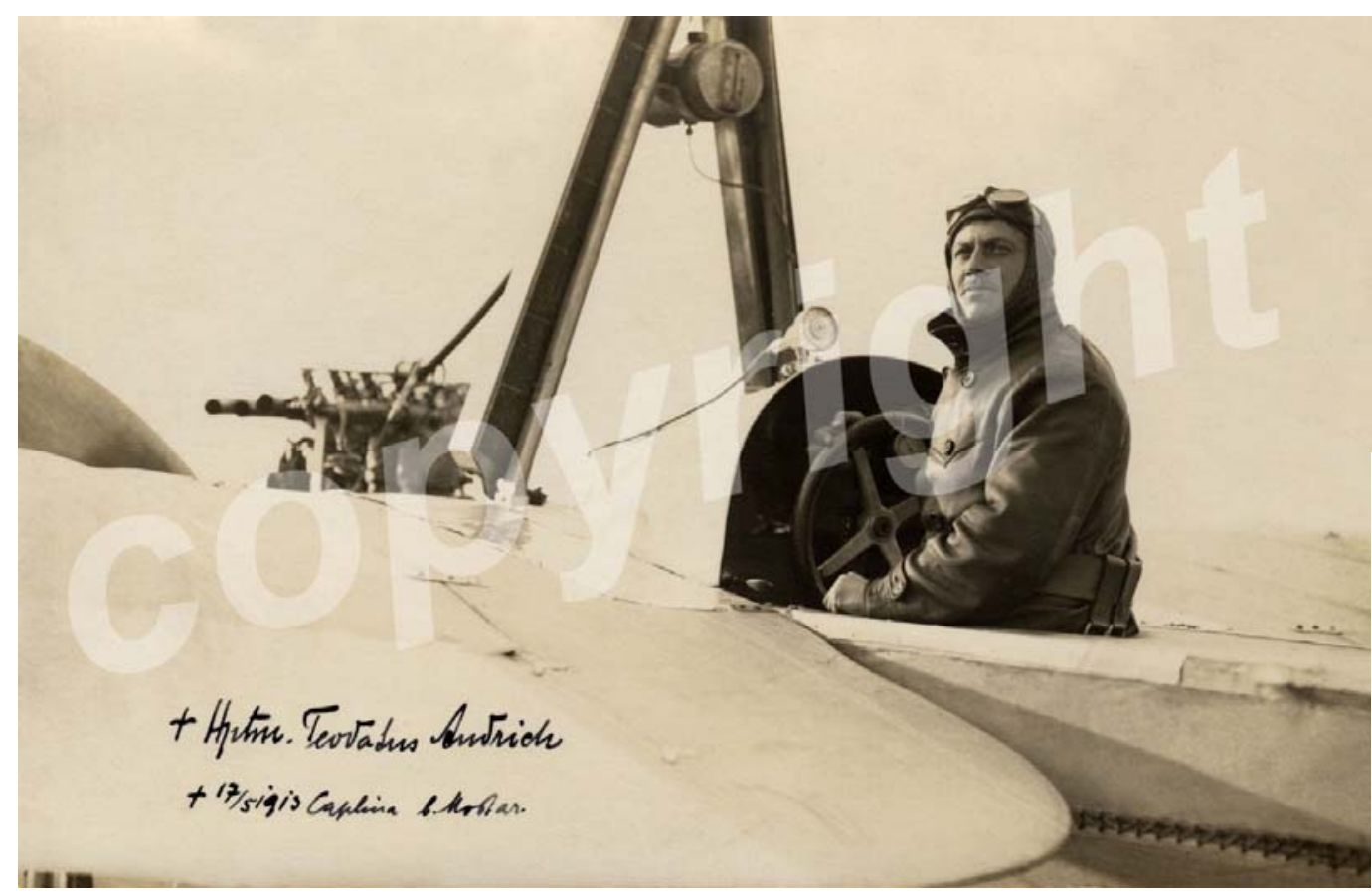

Figure 5. Captain Andrich in 1912 on an Etrich A.// in Wiener Neustadt (by Ch. Plattner) 
Holzschus, G.

The Austro-Hungarian hangars in Mostar - Part I

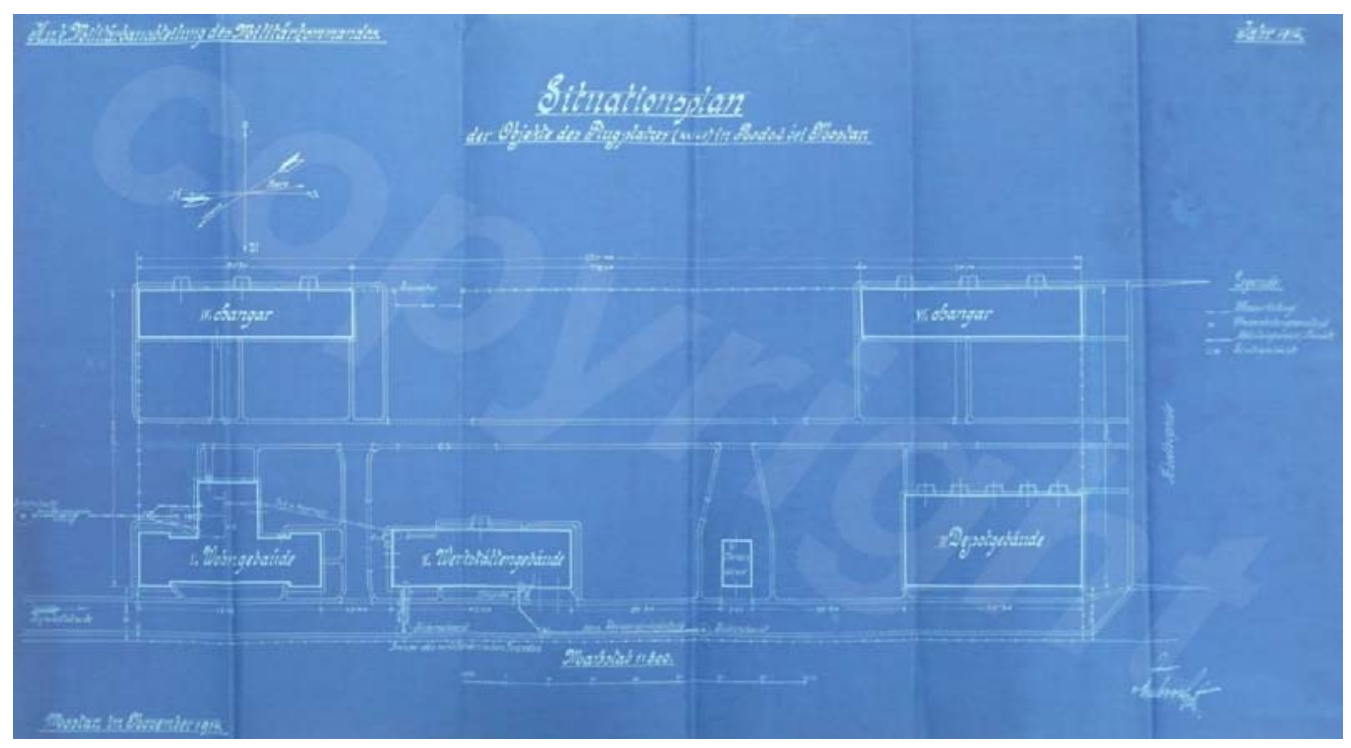

Figure 6. Layout plan of Rodoč air base facilities in 1914 (ÖStA/KA)

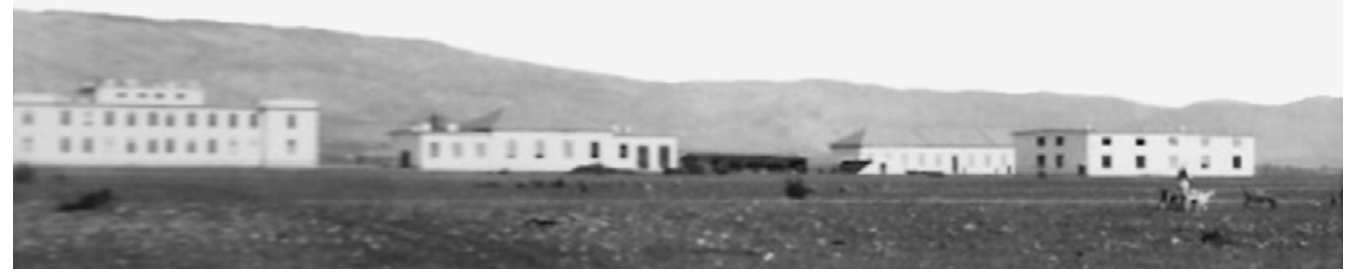

Figure 7. Newly constructed buildings of the aviation park from the west, from left: residential building, workshop, gasoline storage depot and warehouse, the southern aircraft depot is in the background (by Martinović).

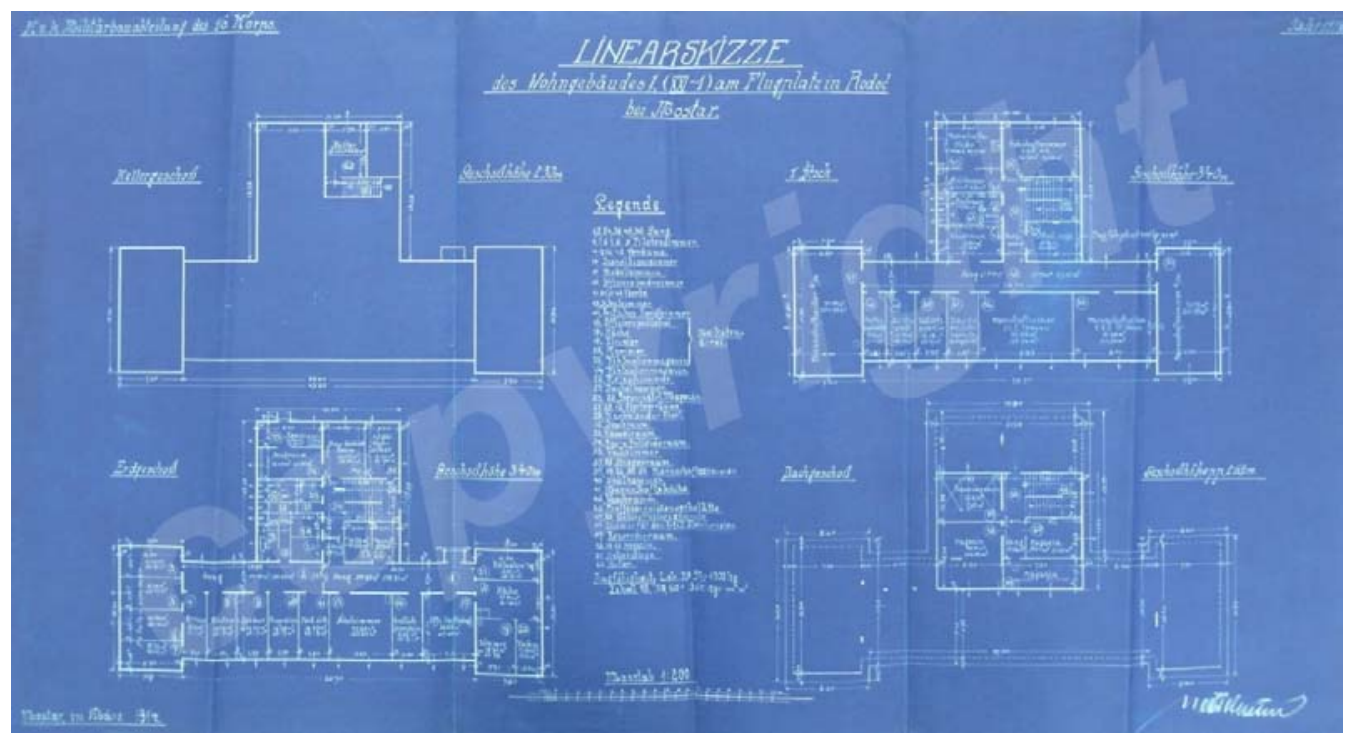

Figure 8. Line sketch of the residential building at the Rodoč airfield in 1914 (ÖStA/KA) 
Holzschus, G.

The Austro-Hungarian hangars in Mostar - Part I

\section{AVIATION PARK 4}

A consequence of the reconstruction of aviation parks in late 1913 was that the Aviation Park no. 4 in Mostar was responsible for setting up and equipping Combat Squadrons (Fliegerkompagnie, abbr. Flik) no. 4 and 6 for the Imperial and Royal $6^{\text {th }}$ Army in case of war. However, Aviation Park 4 had neither the necessary personnel nor suitable combat aircraft to form two aviation units. After the partial mobilization against Serbia, ordered on 26 July 1914, only Flik 4 could go out afield in the direction of Sarajevo on 29 July. Flik 6 had to be established in Vienna-Aspern in September. Only the crew, machines and tools of the Mostar aviation workshop went as support to Flik 6 in the Bay of Kotor.

At the end of August, the fortification command of Mostar registered 42 men, 4 Etrich training monoplanes and 3 bicycles in the aviation park. But then there was a lull about the aviation stronghold near Mostar. A report of the Imperial and Royal Aviation Division of October 1915, addressed to the Ministry of War, advocates the establishment of a Reserve Squadron (Fliegerersatzkompagnie, abbr. Flek) for pilot training in Mostar, which was reportedly constructed as an air base but was not used. According to a survey in September, the airfield would be $1,500 \mathrm{~m}$ long and $790 \mathrm{~m}$ wide, a little rocky and partly ploughed for the purpose of farming. After rolling the ground it would be suitable for pilot training even in winter. The aviation barracks, used as a quarantine facility of the garrison hospital, could be restored to their original purpose after disinfection. In addition to accommodation for 90 men, there would be aircraft depots for six assembled aircraft, a workshop and warehouses for materials and gasoline. The workshop equipment that is unnecessary for Flik 6 in Igalo in the Bay of Kotor could be returned. For reserve squadron's increased needs, it would be necessary to build barracks for further 100 men only. Connection with the Mostar railway station, only $5.5 \mathrm{~km}$ away, is good, and heavy vehicles can use the road in all weather conditions.

The only disadvantage was to bring in ordnance, because when transported by rail to this remote outpost of the Monarchy, the cargo would have to be reloaded from normal to narrow gauge (the so-called Bosnian gauge $760 \mathrm{~mm}$ ). In addition, the iron hangars were not yet delivered either. All this was to last until 9 June 1916, when instructions came to clear the Mostar air base, to repair it, and not to plant anything more at the airfield after the winter grain was harvested. On 6 July 1916, the Reserve Squadron 11 was finally established in Mostar.

\section{RESERVE SQUADRON 11}

The highly increased demand for pilots due to the war events made it urgently needed to establish more reserve squadrons for pilot training. To set up seven squadrons with numbers from 10 to 16 , it was necessary to select the locations near the largest possible garrisons with the appropriate infrastructure. A total of $14,000,000$ kronen was allocated for the construction efforts.

In spring of 1916, the reserve squadrons began to withdraw previously used Etrich single-seater monoplanes and replacing them with double-controlled two-seaters. They had the advantage that crashes of the student pilots could be minimized. With the formation of Flek 10 in Krakow-Rakovice, Flek 11 in Mostar-Rodoč, Flek 12 in Klagenfurt and Flek 13 in Lugoj (Banat), pilot training in Germany was cut back and discontinued in late August. Its results were described as "quite moderate", and the training system with the help of civil companies was assessed as uneconomical. As soon as the student pilots met the requirements for the exam, further flying practice would no longer be guaranteed to them. 
Holzschus, G.

The Austro-Hungarian hangars in Mostar - Part I

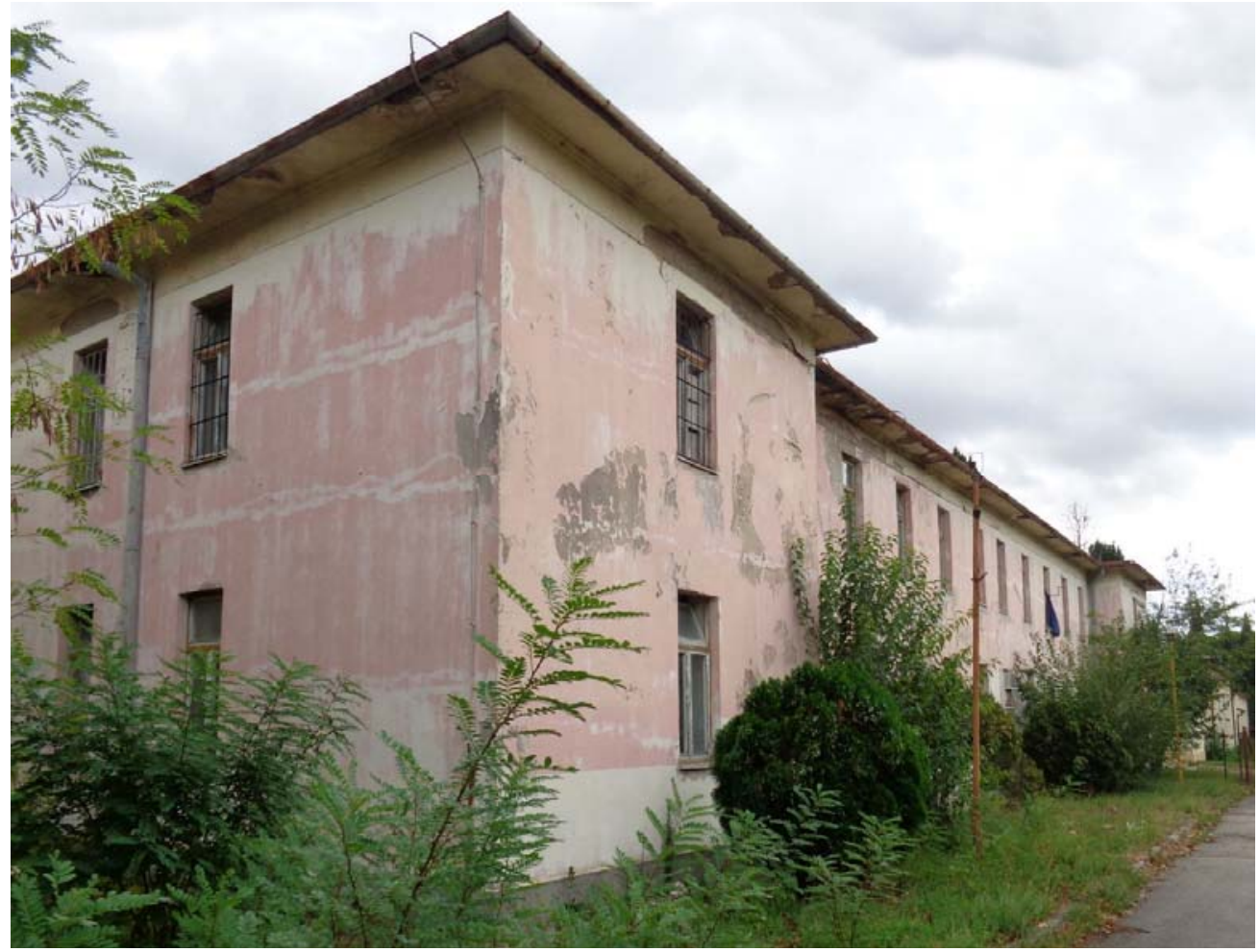

Figure 9. Austro-Hungarian residential building affected by decay, former Rodoč Air Base today (M. Martinović)

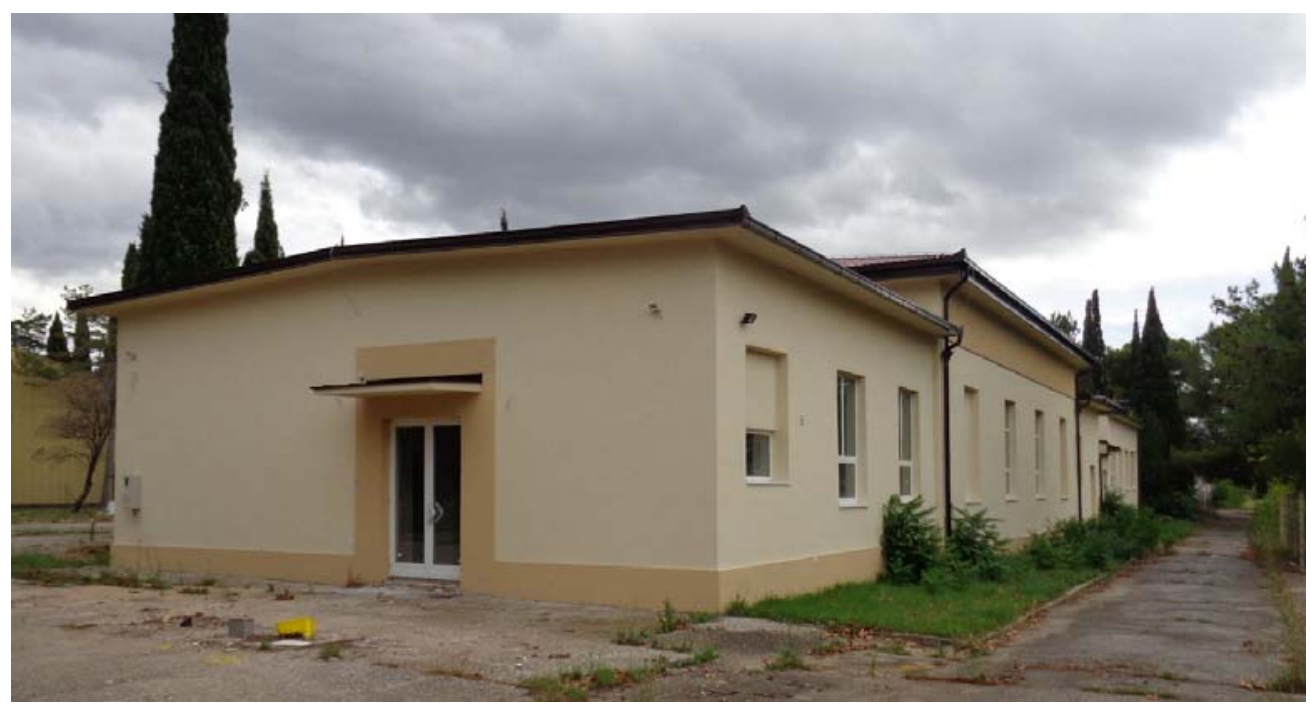

Figure 10. The former air base workshop is used by the University of Mostar (M. Martinović)

Shortage of aircraft proved to be a disadvantage for the education of pilots in remote garrisons like Mostar and Krakow, since the Austro-Hungarian Aviation Arsenal followed the supply of materials very slowly. Mostar was supplied exclusively with training aircraft Brandenburg B.I (Fd) series 05, 06, 75, 76 with $100 \mathrm{HP}$ Mercedes engines, as well in 1917 with series 176 produced in the Fischamend aircraft factory of the Aviation Arsenal. Brandenburg B.I series 06 were into two-seaters with double-control converted biplanes of 
Holzschus, G.

The Austro-Hungarian hangars in Mostar - Part I

the series 05. Many of the planes were crashed and refurbished machines delivered without engines. Due to lack of rubber, there were attempts to fit training aircraft experimentally with wooden wheels instead of rubber tyres. However, these aircraft were strained excessively and put student pilots in the face of unsolvable problems, especially when landing. In August 1916, Flek 11 in Mostar was assigned 2 officers and 26 men as flight students.

On 21 November 1916, training at Flek's was reorganized. Considering the type of aircraft equipment, the training was now conducted in three phases:

Level I: basic training on double-controlled aircraft and about 120 solo flights, within four months on average (Flek's 1, 2, 3, 4, 5, 7, 10, 11 Mostar, 12, 13).

Level II: advanced training with cross-country flights, meeting requirements with aircraft type 17, 33 and 42 (Flek's 8, 9, later also 3).

Level III: training on combat types such as Brandenburg, Oeffag and Fokker for a period of two to three weeks (Flek 6 and later 8 in Wiener Neustadt).

On 11 June 1917, the site management of the Army Air Service approved the construction of further buildings based on plans of Westermann \& Comp. at the Mostar airfield: a three-story residential building for non-commissioned officers and other enlisted ranks, a residential building for officers with wardroom, a storage depot for war equipment, and a two-story building for guards and prisoners. The completion date was planned for 31 August 1918.

\begin{tabular}{|c|c|c|c|c|c|c|c|}
\hline \multicolumn{8}{|c|}{$\begin{array}{c}\text { Reserve Squadron (Fliegerersatzkompagnie) } 11 \text { Mostar } \\
\text { Flying Personnel }\end{array}$} \\
\hline disposition* $^{*}$ & rank & surname & name & StTrpt $^{\star *}$ & arrival date & departure & remarks \\
\hline Kmdt-FP & Hptm & Kahlen, v. & Erich & IR 29 & 20.12.1916 & 06.10 .1917 & $\begin{array}{l}\text { transferred as Commander to } \\
\text { the Training Battalion }\end{array}$ \\
\hline Kmdt-FP & Oblt & Klajc & Wladimir & IR 70 & 10.11.1917 & & ad interim \\
\hline Kmdt-FP & Hptm & Jindra & Otto & GAR 14 & 10.01 .1918 & & from Fliegerkompagnie 1 \\
\hline OffzP-TO & Oblt i.d. Res & Ronsburger & Karl & IR 100 & 19.08.1916 & 02.02 .1918 & to Flik 22/Flik 65 \\
\hline TO & Oblt i.d. Res & Kilga & Benjamin & IR 4 & 09.09 .1916 & 15.10 .1917 & as Technical Officer to Flek 10 \\
\hline OffzP-TO & LdstIngOblt & Mises v., Dr. & Richard & & 02.11 .1016 & & to Flek 4 \\
\hline TO-BO & Oblt i.d. Res & Kostiw & Blasius & SAR 5 & 13.01 .1917 & 10.07.1917 & as Technical Officer to Flik 52 \\
\hline TO & Oblt i.d. Res & Hofmann & Hermann & FjB 4 & 28.07.1917 & 18.10 .1917 & as Technical Officer to Flik 35 \\
\hline TO & Lt i.d. Res & Weber & Eduard & bhFjB 7 & 11.08 .1917 & 02.08 .1918 & als TO to Flying School \\
\hline TO & Lt i.d. Res & Mudrovcic & Dragoljub & SB 13 & 15.10 .1917 & & 1917 to Flek 10 \\
\hline KzIOffz & $\mathrm{Lt}$ & Pelz & Richard & IR 13 & 27.09 .1917 & & Duty Officer \\
\hline $\mathrm{FP}$ & Fwbl & Krisch & Johann & & 01.07 .1916 & & $\begin{array}{l}\text { from Flek } 7,29.04 .17 \text { in air } \\
\text { crash badly injured }\end{array}$ \\
\hline Flgzf & $\mathrm{Kpl}$ & Wiesmayer & Franz & IR 59 & 10.07.1916 & & \\
\hline $\mathrm{FP}$ & $\mathrm{Kpl}$ & Hrabowsky & Leopold & IR 101 & 10.07.1916 & 04.1917 & to Flik 19 \\
\hline Flgzf & Kpl & Bedö & Karl & IR 32 & 10.07.1916 & & $\begin{array}{l}\text { 21.03.18 killed in air crash with } \\
\text { Flik } 24\end{array}$ \\
\hline $\mathrm{FP}$ & Fwbl & Anatol & Renner & & 01.1917 & & \\
\hline Flgzf & Fwbl & Zatek & Richard & & 21.04 .1917 & & from Flek 4 \\
\hline $\mathrm{FP}$ & Fwbl & Gajic & Stefan & IR 78 & 30.04 .1917 & & from Flik 14, to Flek 1 \\
\hline $\mathrm{FP}$ & Fwbl & Skraba & Boleslaus & & 05.05 .1917 & & from Flik 18 \\
\hline Flgzf & $\mathrm{Kpl}$ & Willrader & Rudolf & & 26.06 .1917 & & \\
\hline Flgzf & Kpl & Rotter & Karl & & 10.09 .1917 & & from Flek 8 \\
\hline
\end{tabular}

* Kmdt: Commander, FP: Combat Pilot, OffzP: Pilot Officer, TO: Technical Officer, KzlOffz: Duty Officer, Flgzf: Pilot.

** Stammtruppenteil: previous army service, IR: Infanterieregiment. 